Патоморфологія та гістологія : атлас / за ред.: Д. Д. Зербіно, М. М. Багрія, Я. Я. Боднара, В. А. Діброви [та ін.] - Вінниця : Нова книга, 2016. - 800 с. : іл.

\title{
Мова: українська
}

\section{Рецензенти:}

Гичка С. Г. - доктор медичних наук, професор, академік АН ВШ України, завідувач кафедри патологічної анатоміі, гістологіі та судової медицини Київського медичного університету УАНМ, президент Асоціації патологів України.

Сільченко В. П. - доктор медичних наук, професор, завідувач кафедри патологічної та топографічної анатомії Національної медичної академії післядипломної освіти імені П. Л. Шупика.

Чайкобський Ю. Б. - доктор медичних наук, професор, член-кореспондент НАМН України, член Міжнародної академії патології, заслужений діяч науки $і$ техніки України, лауреат Державної премії України, завідувач кафедри гістології та ембріології Національного медичного університету імені О. О. Богомольця, президент Наукового товариства анатомів, гістологів, ембріологів та топографоанатомів України.

Федонюк.Л. Я. - доктор медичних наук, професор кафедри гістологіі, цитологіі та ембріології Буковинського державного медичного університету (до 2012 р.); завідувач кафедри медичної біологіі ДВНЗ "Тернопільський державний медичний університет імені I. Я. Горбачевського МО3 України" (3 2012 p.).

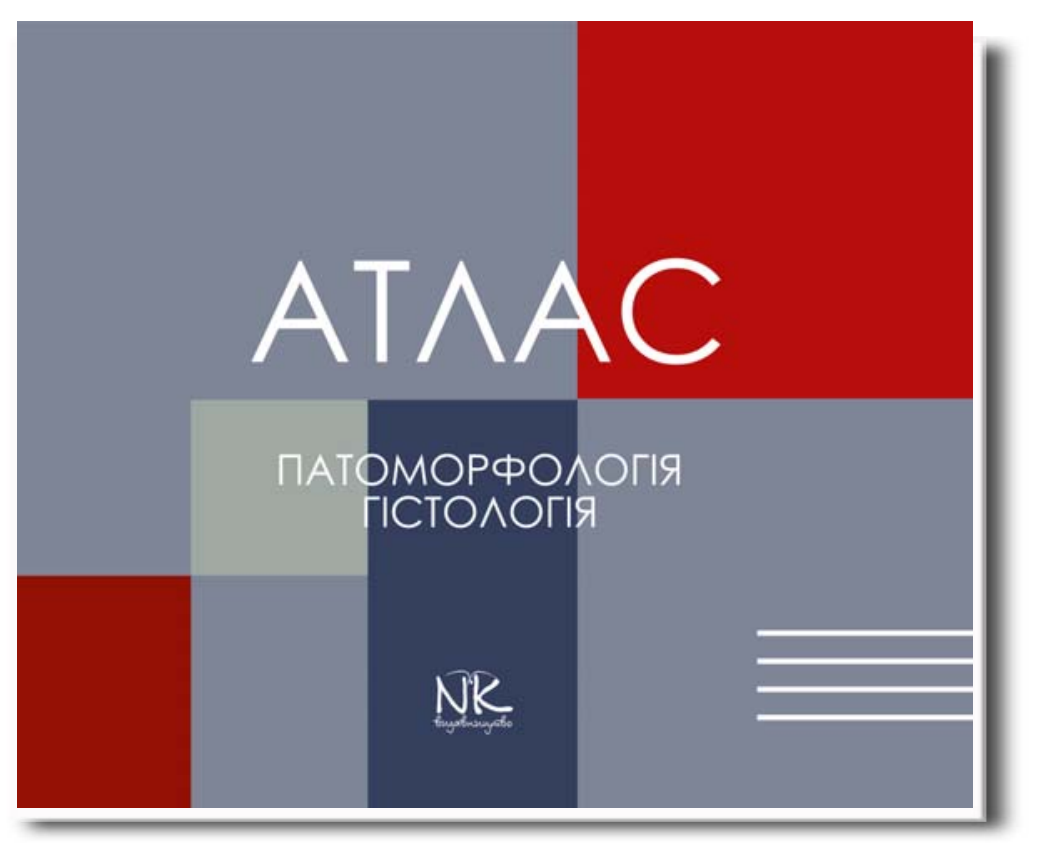


В атласі у систематнзованому порядку, внходячн із сучасннх познцій, відображено гістологічну будову тканнн і органів, патогістологічні проявн загальнопатологічннх процесів, цнто- і патоморфологію захворювань усіх снстем, органів і тканнн організму людннн. Усі мікрофотографії представлені орнгінальннмн гістологічними та цитологічннмн препаратамн.

Атлас складається з двох частнн: гістології та патоморфологіі, шо дозволяє проводитн порівняння патологічннх процесів із нормальною гістоархітектонікою тканнн і органів.

Атлас прнзначеннй для студентів меднчннх ВН3 за спеціальностями «Лікувальна справа», «Педіатрія», «Стоматологія», які внвчають гістологію та патоморфологію, для лікарів-інтернів, магістрантів, аспірантів, клінічннх ордннаторів за спеціальностями «Патологічна анатомія», «Дитяча патологічна анатомія», лікарів-патологоанатомів, внкладачів меднчннх ВНЗ і лікарів різннх спеціальностей, у практиці якнх зустрічаються патологічні станн та захворювання, патогістологічна картнна якнх тут продемонстрована.

\section{КОРОТКИЙ ЗМІСТ}

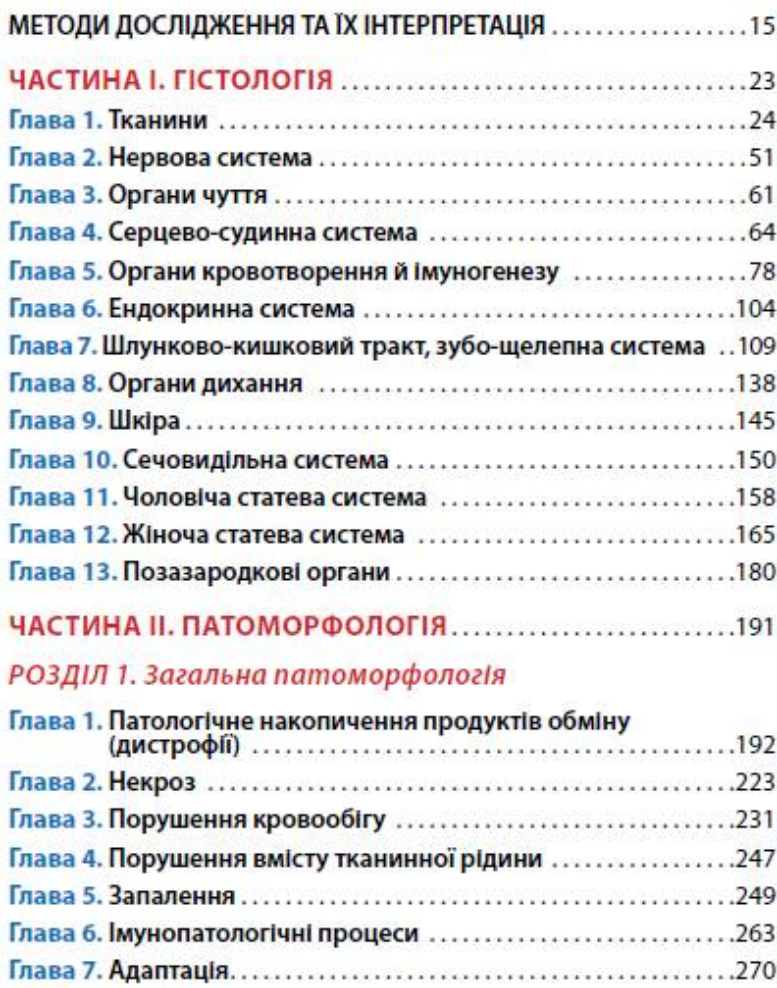

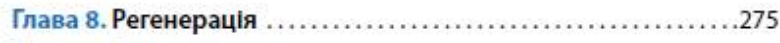

Глава 9. Склероз ....................................279

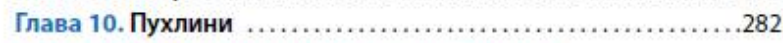

РОзділ 2. Спеціальна патоморфологія

Глава 11. Хвороби системи крові: анемії ....................402

Глава 12. Хвороби серцево-судинної системи ..............406

Глава 13. Системні захворювання сполучної тканини ........420

Глава 14. Хвороби органів дихання …....................424

Глава 15. Хвороби зубо-щелепної системи й органів ротової порожнини .............................445

Глава 16. Хвороби шлунково-кишкового тракту ............485

Глава 17. Хвороби сечовидільної системи ..................532

Глава 18. Хвороби залоз внутрішньої секреції ...............558

Глава 19. Хвороби чоловічих статевих органів ...............575

Глава 20. Хвороби жіночих статевих органів .................552

Глава 21. Хвороби грудних залоз .......................632

Глава 22. Хвороби вагітності та післяпологового періоду ....656

Глава 23. Хвороби центральної нервової системи ............669

Глава 24. Хвороби опорно-рухового апарату ..............6.671

Глава 25. Патологія шкіри .................................676

Глава 26. Лімфаденопатії ...............................694

Глава 27. Хвороби дитячого віку...........................708

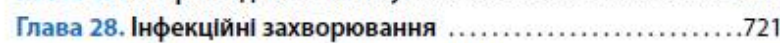

СПИСОК РЕКОМЕНДОВАНОІ ЛІТЕРАТУРИ ...................762

ПРЕДМЕТНИЙ ПОКАЖЧИК ...............................764

ПОКАЖЧИК МІКРОФОТОГРАФІЙ ..........................775 